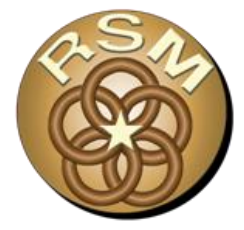

\title{
Effects of Bank Stabilization on Regional Sediment Management: Lessons Learned from the Kansas River and Grand River Basins
}

by Aaron Williams and John Shelley

PURPOSE: Accumulation of sediment has and continues to be a major problem facing reservoir managers and stakeholders. Sediment accumulation can be reduced by either preventing sediment from entering the reservoir or by removing it once it has been deposited, typically by dredging and upland disposal. Sediment transported into reservoirs generates from overland runoff and erosion of river beds and banks from upstream watersheds. This Regional Sediment Management Technical Note (RSM-TN) presents results of an analysis of bank stabilization as a means of regional sediment management within the US Army Corps of Engineers (USACE), Kansas City District (NWK), and distills lessons learned from previous bank stabilization project successes and failures.

INTRODUCTION: USACE has a long history of streambank stabilization. Section 14 of the 1946 Flood Control Act, as amended, provides authority for USACE to plan and construct emergency streambank and shoreline protection projects to protect threatened highways, highway bridge approaches, and other nonprofit public facilities. These and similar projects have not historically counted the reduction in sediment loading to the river as a benefit during alternatives analysis. However, in many cases downstream projects including reservoirs, actively maintained navigation channels, and sensitive floodplain habitats can substantially benefit from the sediment reduction.

This RSM-TN includes results of an analysis of two categories of streambank stabilization projects. The first category includes streambank stabilization projects built by the Kansas Water Office (KWO), State of Kansas agencies upstream of USACE reservoirs in the Kansas River Basin. Many watersheds within the Kansas River Basin derive the predominant portion of their sediment load from erosion of beds and banks rather than from overland runoff (Juracek and Ziegler 2009). A disproportionate amount of the total bank-derived sediment comes from a limited number of tall banks with high erosion rates (USACE 2011). The KWO estimated that sediment load reduction through stabilization of these bank erosion hot spots could be as much as 21 times more cost effective than traditional reservoir dredging (Gnau 2013). Approximately 13 million cubic yards per year ( $\mathrm{M} \mathrm{yd}^{3} /$ year) of sediment are deposited in Tuttle Creek, Milford, Kanopolis, Wilson, Harlan County, and Wakunda Lakes (Shelley et al. 2016). The State of Kansas has constructed miles of streambank stabilization in an effort to reduce the sediment loading to the reservoirs. Ten projects were analyzed in the study and reported in this RSM-TN.

The second category includes eight Section 14 streambank stabilization projects constructed by the NWK upstream of ecologically sensitive floodplain habitats in the Grand River Basin. The purpose of these projects was to protect critical infrastructure, typically bridges and roads. The targeted banks were not as erosive, and significantly more rock was used in the projects when compared to the State of Kansas projects. Figure 1 shows a general location map of the bank stabilization projects. Figures 2 and 3 provide maps of the Kansas River and Grand River Basins, respectively. 
ERDC/TN RSM-20-1

January 2020

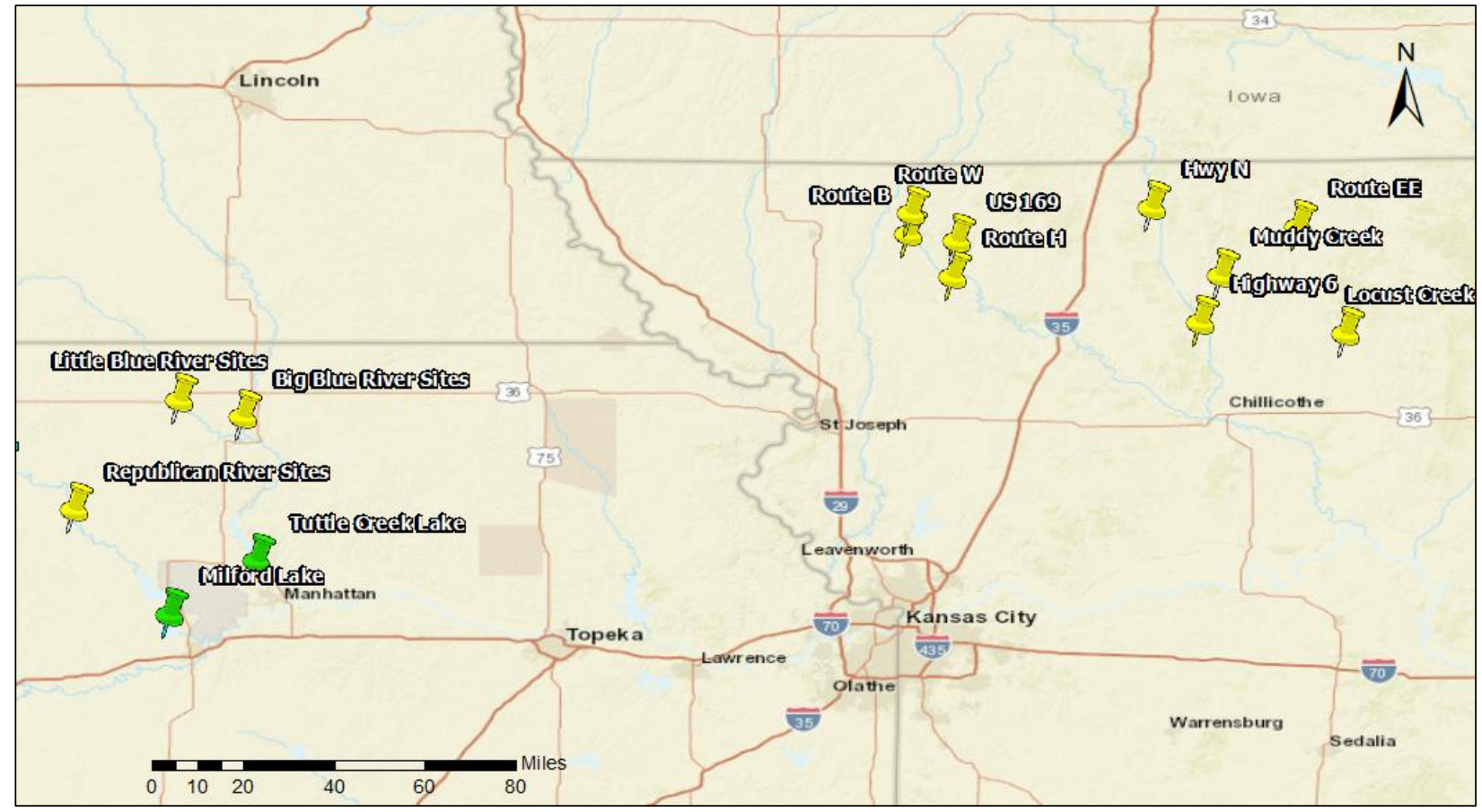

Figure 1. General location map of streambank stabilization projects.

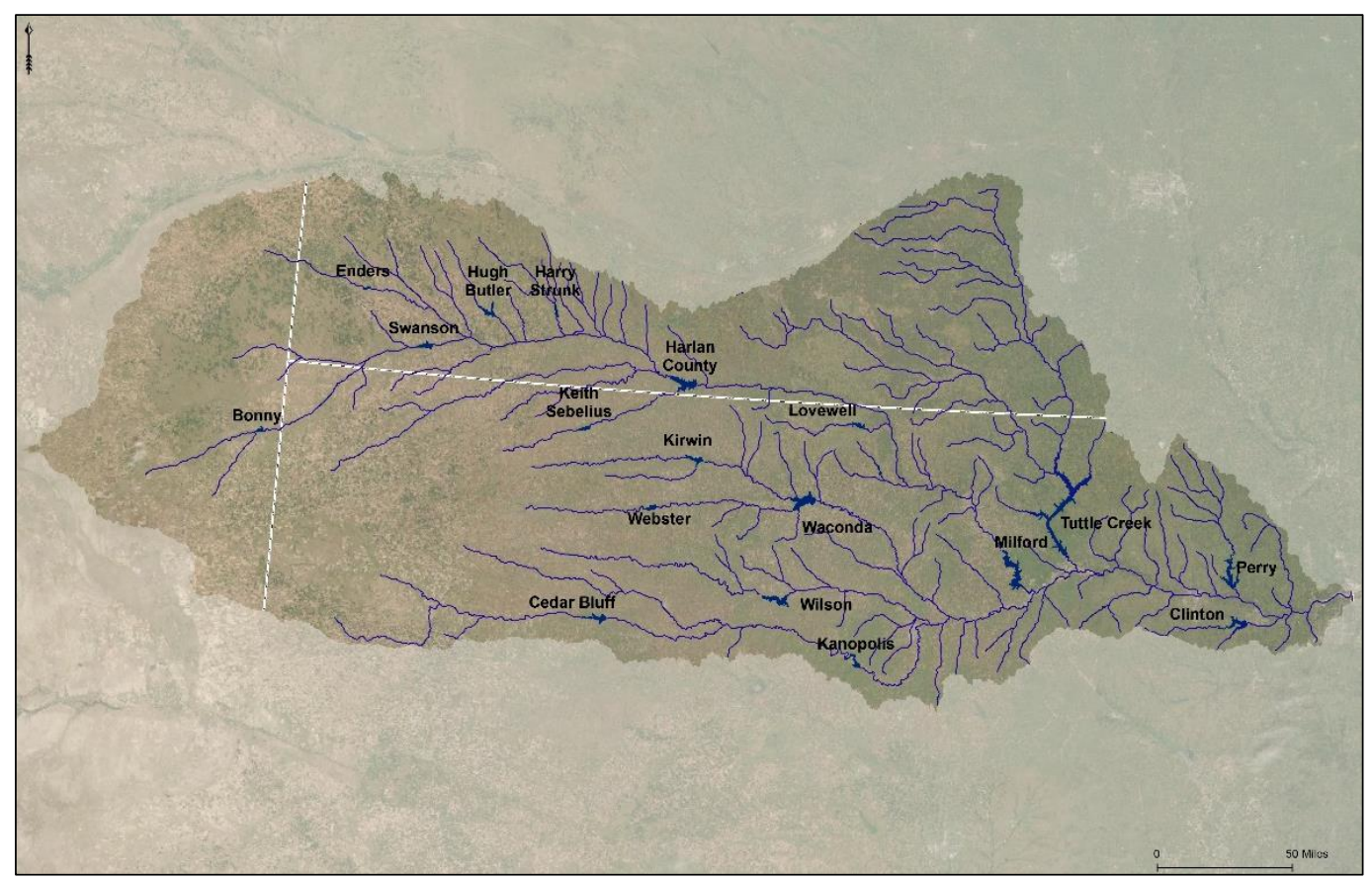

Figure 2. Kansas River Basin map. 


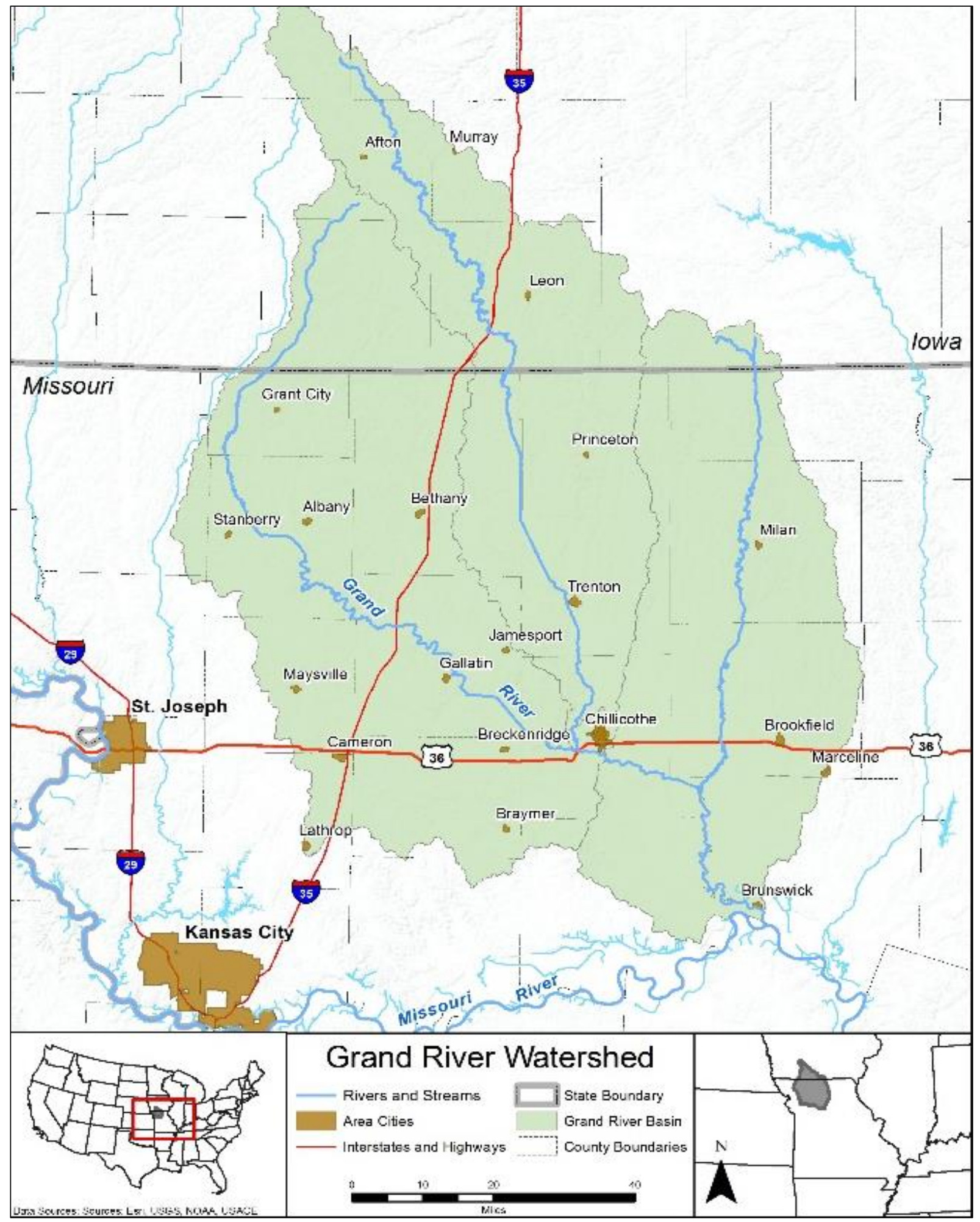

Figure 3. Grand River Basin map.

COMPARISON TO DREDGING COSTS: A first approximation for the economic value of the streambank stabilization from an RSM perspective can be estimated by the cost to dredge an equivalent volume of sediment from a downstream reservoir. A 2016 reservoir dredging project at 
John Redmond Reservoir removed $3 \mathrm{M} \mathrm{yd}^{3}$ at a cost of $\$ 20 \mathrm{M}$, or $\$ 6.67 / \mathrm{yd}^{3}$ (KWO 2016). Promising and potentially less expensive dredging techniques such as hydrosuction (Shelley 2019) and water-injection dredging are currently being analyzed for effectiveness on reservoirs within the Kansas River Basin. However, due to unknowns, limitations, and current regulatory hurdles associated with these methods, this study used a sediment removal cost of $\$ 6.67 / \mathrm{yd}^{3}$ to assess the monetary value of reducing sediment loads via streambank stabilization. The additional benefits of streambank stabilization that accrue to local landowners are not included.

SEDIMENT REDUCTION COMPUTATIONS: The reduction in sediment loading due to the construction of bank stabilization projects was computed in three steps: (1) aerial photography from 1991 to 2008, along with the construction dates, provided an annual area erosion rate; (2) the annual area erosion rate was transformed into an annual volume using field measurements for bank heights; and (3) sediment size gradation samples were used to compute the volumetric erosion rate of only the wash load portion of bank sediments. Wash load that enters streams from eroding banks quickly transports downstream at approximately the same velocity as the water (Biedenharn et al. 2006) and deposits in the reservoirs. Reducing the wash load results in a comparable near-term reduction in sediment loading to the reservoir. Conversely, a reduction in the coarse fraction of the bank material could take decades to translate into reduced sediment loading to the reservoirs. For this study, only wash load material is used for the volume estimates.

For the purpose of this study, wash load was defined as the grain size for which $10 \%$ of bed mixture is finer (Einstein 1950). Sediment samples were collected during field assessments and analyzed for particle size. One requirement in the wash load definition is that bed samples are not collected at low flows (Einstein 1950). Due to low flow conditions during sampling for this study, the particle size and percentage of bank material constituting wash load is likely conservatively low, which will lead to an underestimation of the sediment reduction from the bank stabilization. Figure 4 presents the results of the size gradation analysis of the bed and banks. For each project, the annual erosion volume rate was multiplied by the percent of the bank material computed to be wash load to estimate the reduction in wash load. This quantity was then multiplied by $\$ 6.67 / \mathrm{yd}^{3}$ (KWO 2016) to estimate the annual cost to dredge an equivalent quantity of sediment.

ROCK QUANTITIES: Design documents listing the quantity of rock used during construction are available for 7 of the 10 State of Kansas projects. Rock quantities for the remaining three projects without design documents were estimated using a relationship between project length and rock quantity developed from the seven projects with known rock quantities. Only 1 of the 10 State of Kansas projects has information available for the volume of earthwork required during construction, so a relationship was developed between the quantity of rock used and volume of earthwork required from the Section 14 projects. Due to the varying level of design of the eight Section 14 projects constructed in the Grand River Basin, only the four projects with known rock and earthwork quantities were used in the sediment reduction analyses. Estimated project costs are calculated by summing the cost to purchase and place rock, assumed to be $\$ 50 /$ ton, and the cost to perform earthwork, assumed to be $\$ 6.40 / \mathrm{yd}^{3}$. These prices are based on recent cost estimates developed within the NWK for similar projects in the same vicinity. While the estimated project costs in this study (on average $\$ 65$ per linear foot) are a simplified presentation of actual costs, they fall within the anticipated costs to implement streambank stabilization (USACE 2011). 


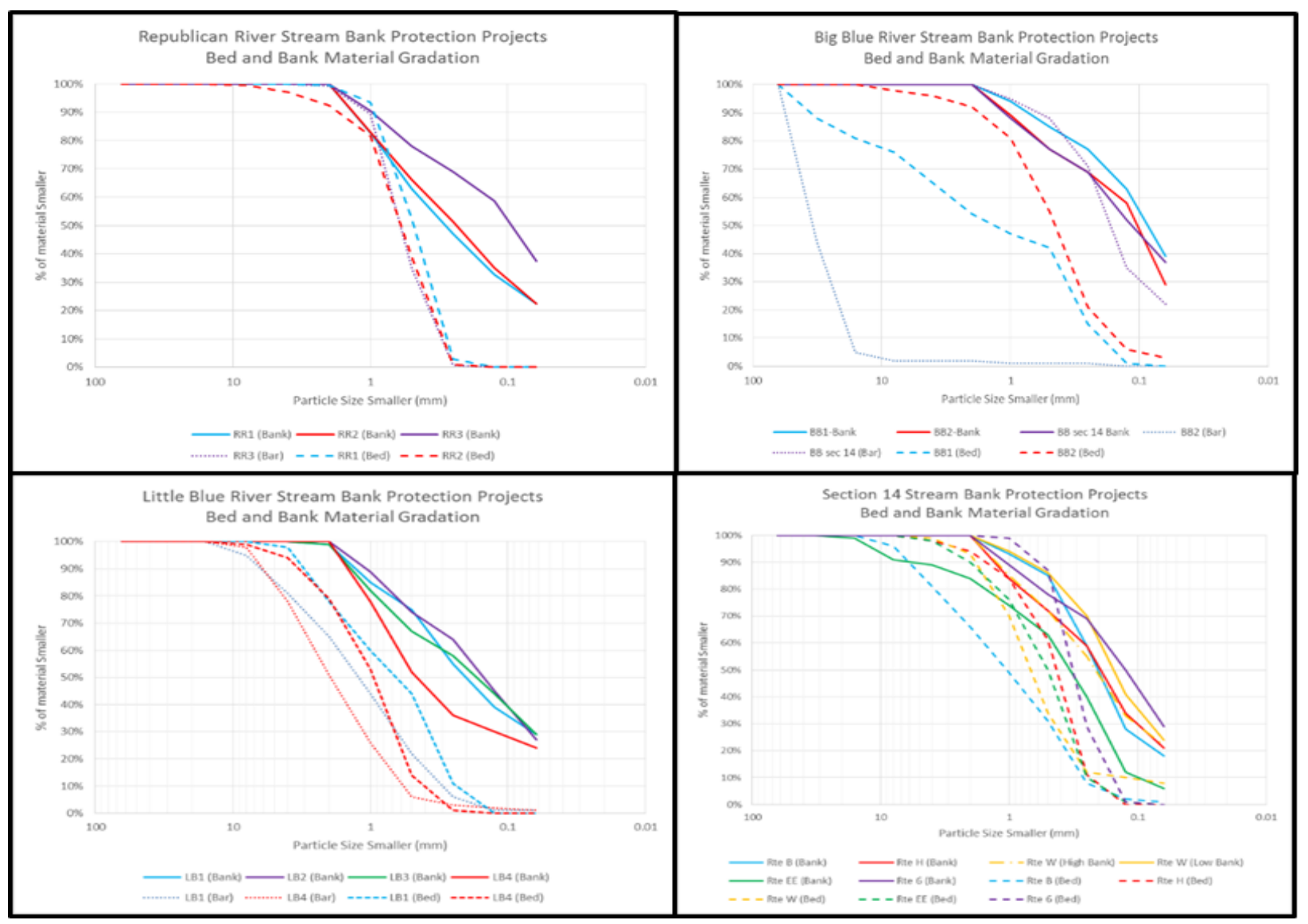

Figure 4. Bed/bank sample gradations.

RESULTS: Tables 1-4 provide results of the sediment reduction and project cost analyses. As seen, the 10 State of Kansas bank stabilization projects upstream of USACE reservoirs are estimated to be on average 14 times more cost effective than reservoir dredging, assuming a 20 -year design life. For the four Section 14 projects in the Grand River Basin designed to protect infrastructure, bank stabilization is estimated to be approximately equal to the cost of reservoir dredging over a 20-year period. The actual sediment reduction benefits from these Section 14 projects result from decreasing negative impacts to ecologically sensitive floodplain habitats downstream. Sediment removal from these habitats would be much more expensive than the $\$ 6.67 / \mathrm{yd}^{3}$ and also comes at the expense of having to damage the habitat to remove the sediment. 


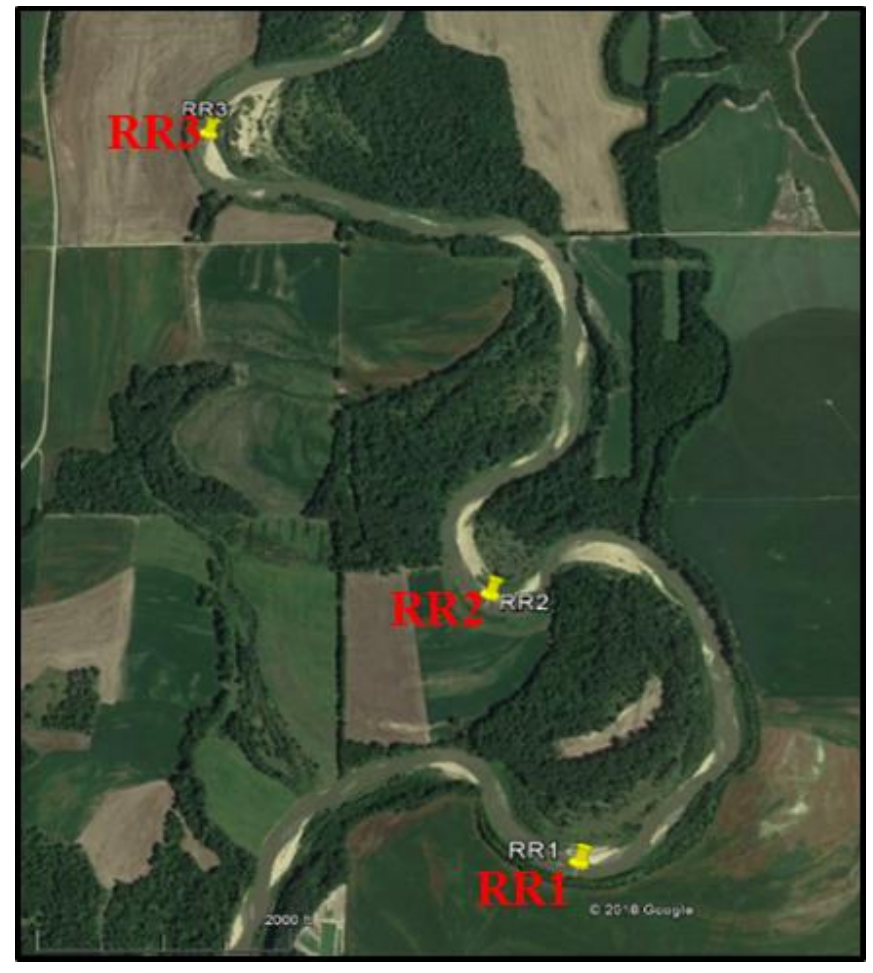

\begin{tabular}{|c|c|c|c|}
\hline \multicolumn{4}{|c|}{ Republican River } \\
\hline Site Identifier & RR1 & RR2 & RR3* \\
\hline Year Constructed & 2004 & 2006 & 2004 \\
\hline Erosion Area (ac) & 7.5 & 5.5 & 10.6 \\
\hline Bank Height (ft) & 13.8 & 13.8 & 13.8 \\
\hline $\begin{array}{c}\text { Erosion Rate } \\
\left(\mathrm{yd}^{3} / \mathrm{yr}\right)\end{array}$ & 12,700 & 8,200 & 18,100 \\
\hline \% Bank Wash Load & $71 \%$ & $55 \%$ & $49 \%$ \\
\hline $\begin{array}{l}20 \text { yr Wash Load } \\
\text { Reduction }\left(\mathrm{yd}^{3}\right)\end{array}$ & 180,340 & 90,200 & $62,100^{*}$ \\
\hline $\begin{array}{l}\text { Quantity of Rock } \\
\text { (ton) }\end{array}$ & 1,844 & 1,685 & 1,727 \\
\hline $\begin{array}{c}\text { Volume of } \\
\text { Earthwork }\left(\mathrm{yd}^{3}\right)\end{array}$ & 706 & 645 & 661 \\
\hline $\begin{array}{l}\text { Estimated Project } \\
\text { Cost }\end{array}$ & $\$ 97,000$ & $\$ 88,000$ & $\$ 91,000$ \\
\hline $\begin{array}{l}20 \text { yr Wash Load } \\
\text { Dredging Cost }\end{array}$ & $\$ 1,200,000$ & $\$ 600,000$ & $\$ 410,000$ \\
\hline
\end{tabular}

*Project failed after 7 years.

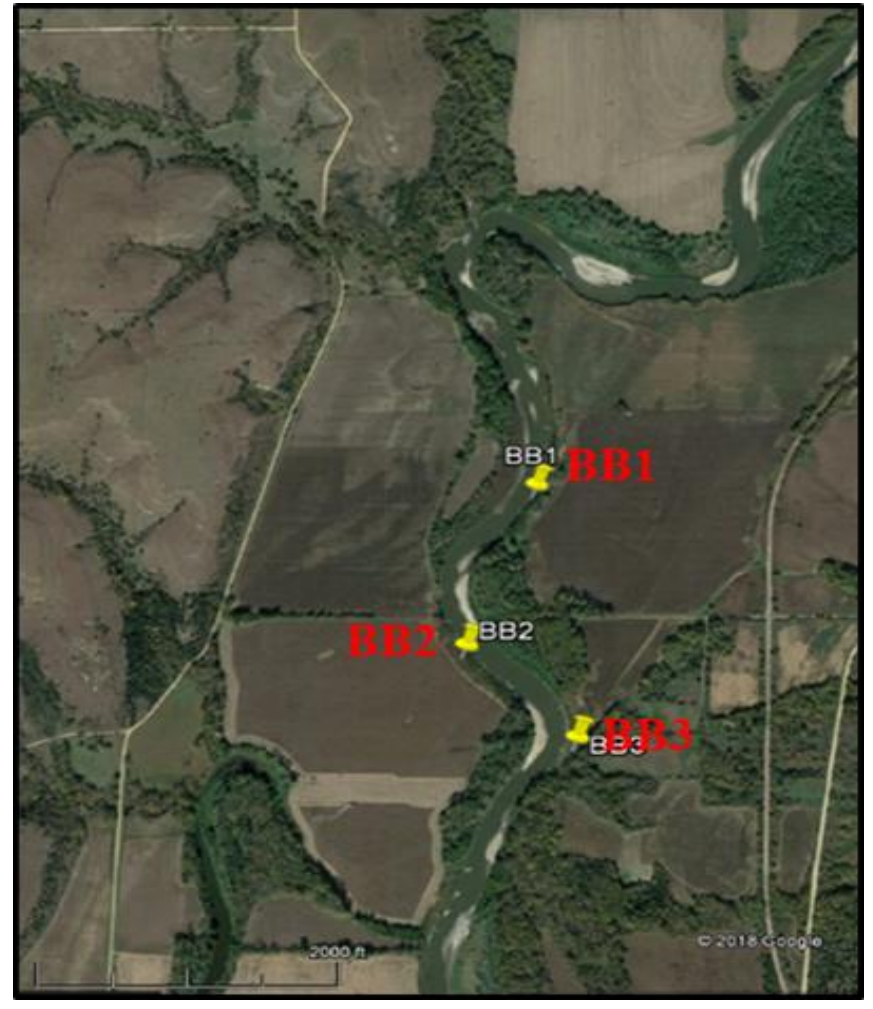

Table 2. Big Blue River site map and project summary.

\begin{tabular}{||c|c|c|c||}
\hline \hline \multicolumn{4}{|c||}{ Big Blue River } \\
\hline Site Identifier & BB1 & BB2 & BB3 \\
\hline Year Constructed & 2003 & 2010 & 2010 \\
\hline Erosion Area (ac) & 6.2 & 3.8 & 2.3 \\
\hline Bank Height (ft) & 20.3 & 19.4 & 22.3 \\
\hline Erosion Rate (yd $3 / \mathrm{yr})$ & 16,900 & 7,000 & 4,800 \\
\hline$\%$ Bank Wash Load & $72 \%$ & $61 \%$ & $60 \%$ \\
\hline $\begin{array}{c}20 \text { yr Wash Load } \\
\text { Reduction (yd }{ }^{3} \text { ) }\end{array}$ & 243,360 & 85,400 & 57,600 \\
\hline $\begin{array}{c}\text { Quantity of Rock } \\
\text { (ton) }\end{array}$ & 993 & $1,164^{*}$ & $744^{*}$ \\
\hline $\begin{array}{c}\text { Volume of } \\
\left.\text { Earthwork (yd }{ }^{3}\right)\end{array}$ & 380 & 446 & 285 \\
\hline $\begin{array}{c}\text { Estimated Project } \\
\text { Cost }\end{array}$ & $\$ 53,000$ & $\$ 61,000$ & $\$ 39,000$ \\
\hline $\begin{array}{c}20 \text { yr Wash Load } \\
\text { Dredging Cost }\end{array}$ & $\$ 1,620,000$ & $\$ 570,000$ & $\$ 380,000$ \\
\hline
\end{tabular}

*Rock volume estimated based on project length (no design documents available). 
ERDC/TN RSM-20-1

January 2020

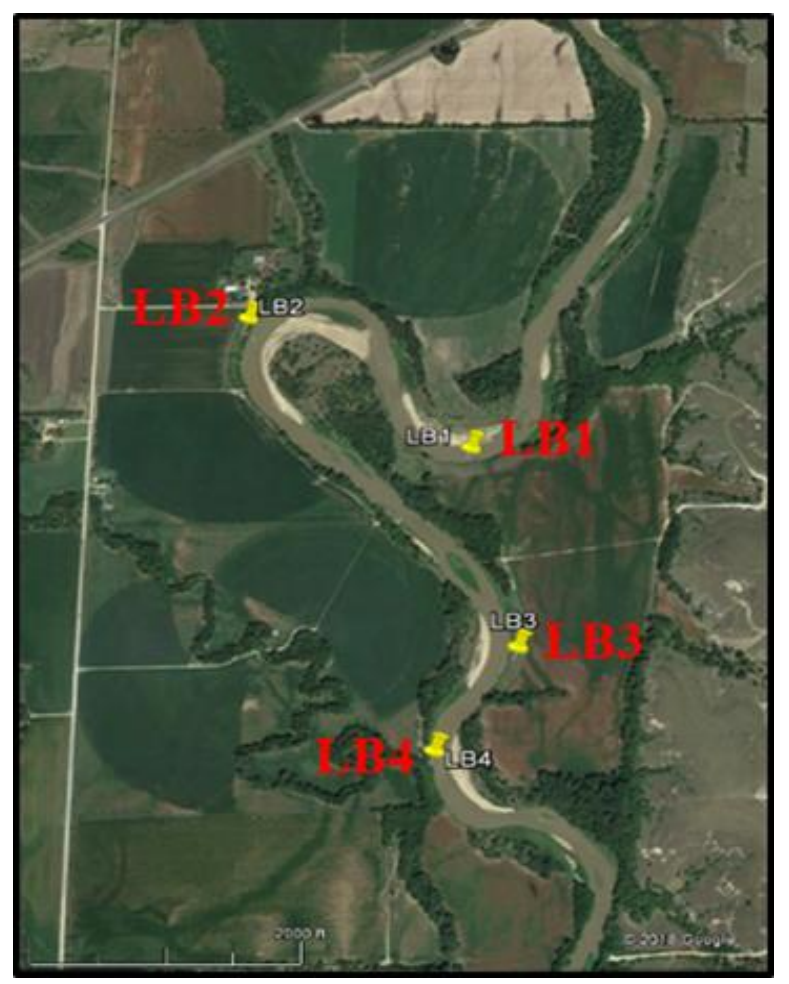

\begin{tabular}{|c|c|c|c|c|}
\hline \multicolumn{5}{|c|}{ Little Blue River } \\
\hline Site Identifier & LB1 & LB2 & LB3 & LB4 \\
\hline $\begin{array}{c}\text { Year } \\
\text { Constructed }\end{array}$ & 2002 & 2004 & 2002 & 2011 \\
\hline $\begin{array}{c}\text { Erosion Area } \\
\text { (ac) }\end{array}$ & 7.2 & 7.1 & 1.5 & 2.0 \\
\hline Bank Height $(\mathrm{ft})$ & 21.0 & 21.0 & 17.9 & 21.0 \\
\hline $\begin{array}{c}\text { Erosion Rate } \\
\left(\mathrm{yd}^{3} / \mathrm{yr}\right)\end{array}$ & 22,000 & 18,500 & 3,900 & 3,900 \\
\hline $\begin{array}{c}\% \text { Bank Wash } \\
\text { Load }\end{array}$ & $54 \%$ & $62 \%$ & $57 \%$ & $52 \%$ \\
\hline \begin{tabular}{|c|}
20 yr Wash \\
Load Reduction \\
$\left(\mathrm{yd}^{3}\right)$
\end{tabular} & 237,600 & 229,400 & 44,460 & 40,560 \\
\hline $\begin{array}{c}\text { Quantity of Rock } \\
\text { (ton) }\end{array}$ & 1,017 & $1,080^{*}$ & 2,016 & 1,121 \\
\hline \begin{tabular}{|c|} 
Volume of \\
Earthwork $\left(\mathrm{yd}^{3}\right)$
\end{tabular} & 390 & 414 & 772 & 429 \\
\hline $\begin{array}{c}\text { Estimated Rock } \\
\text { Cost }\end{array}$ & $\$ 53,000$ & $\$ 57,000$ & $\$ 106,000$ & $\$ 59,000$ \\
\hline \begin{tabular}{|c|}
20 yr Wash \\
Load Dredging \\
Cost
\end{tabular} & $\$ 1,580,000$ & $\$ 1,530,000$ & $\$ 300,000$ & $\$ 270,000$ \\
\hline
\end{tabular}

*Rock Volume Estimated Based on Project Length (No Design Documents Available)

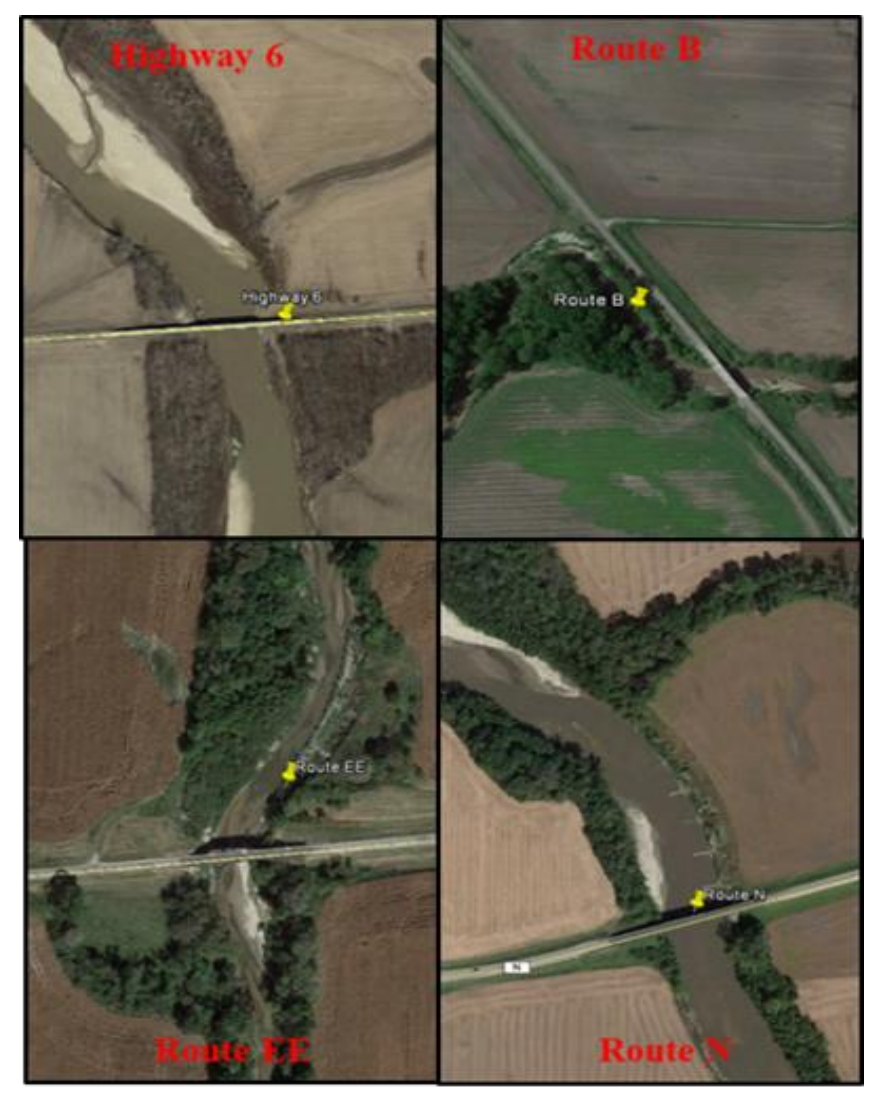

\begin{tabular}{|c|c|c|c|c|}
\hline \multicolumn{5}{|c|}{ Section 14 (Grand River Basin) } \\
\hline $\begin{array}{c}\text { Site } \\
\text { Identifier }\end{array}$ & $\begin{array}{c}\text { Highway } \\
6\end{array}$ & Route B & Route EE & Route N \\
\hline $\begin{array}{c}\text { Year } \\
\text { Constructed }\end{array}$ & 2005 & 2012 & 2011 & 2013 \\
\hline $\begin{array}{c}\text { Erosion Area } \\
\text { (ac) }\end{array}$ & 2.4 & 0.2 & 1.2 & 1.2 \\
\hline $\begin{array}{c}\text { Bank Height } \\
(\mathrm{ft})\end{array}$ & 25.0 & 16.0 & 24.0 & 26.0 \\
\hline $\begin{array}{c}\text { Erosion Rate } \\
\left(\mathrm{yd}^{3} / \mathrm{yr}\right)\end{array}$ & 10,756 & 323 & 3,098 & 2,961 \\
\hline $\begin{array}{c}\text { \% Bank } \\
\text { Wash Load }\end{array}$ & $54 \%$ & $55 \%$ & $55 \%$ & $56 \%$ \\
\hline $\begin{array}{c}20 \text { yr Wash } \\
\text { Load } \\
\text { Reduction } \\
\left(\mathrm{yd}^{3}\right)\end{array}$ & 116,200 & 3,500 & 34,100 & 33,200 \\
\hline $\begin{array}{l}\text { Quantity of } \\
\text { Rock (ton) }\end{array}$ & 10,900 & 5,140 & 5,230 & 4,362 \\
\hline $\begin{array}{c}\text { Volume of } \\
\text { Earthwork } \\
\left(\mathrm{yd}^{3}\right)\end{array}$ & 2,658 & 1,365 & 3,520 & 1,527 \\
\hline $\begin{array}{c}\text { Estimated } \\
\text { Project Cost }\end{array}$ & $\$ 562,000$ & $\$ 257,000$ & $\$ 261,500$ & $\$ 218,100$ \\
\hline $\begin{array}{l}20 \text { yr Wash } \\
\text { Load } \\
\text { Dredging } \\
\text { Cost }\end{array}$ & $\$ 780,000$ & $\$ 20,000$ & $\$ 230,000$ & $\$ 220,000$ \\
\hline
\end{tabular}


PROJECT FAILURES: While designers strive to ensure bank stabilization projects are successful, knowledge can be gained from project failures. The three Republican River projects analyzed in this study are very near each other and were constructed around the same time but have varying degrees of success. A general location map of the Republican River projects is shown in Figure 5. Project RR3, the most upstream project on the Republican River, failed completely. The bendway weirs are now buried in the point bar on the opposite bank (Figures 6 and 7) allowing approximately $48,000 \mathrm{yd}^{3}$ of additional sediment to be eroded from the bank. Project RR1 is mostly functioning; however, flanking of two weirs has occurred, which has reduced the project effectiveness and useful life. Project RR2 is fully functional with no flanked weirs but has an atypical design from the other streambank protection projects analyzed in this study. The major project features of RR2 were rock closure structure to prevent flow through a side channel that had formed during high flows. Aerial photos showing the progression of the project RR3 failure are included in Figure 6. Figure 7 shows a flanked structure on project RR3, when the photo was taken during a field assessment in November 2017.

Projects RR1 and RR3 were constructed in 2004, and RR2 was constructed in 2006. Based on historic aerial photography, the RR3 project failed between 9/2010 to 9/2012. Flows during this period (Figure 8) indicated the failure most likely occurred in the spring of 2011 when a $50 \%$ to $20 \%$ annual exceedance (2- to 5-year) flow event occurred. All three projects experienced the same event, and the best functioning project was completed more recently. Flows in the Republican River around the anticipated failure of project RR3, including results of a Log Pearson III Flood Frequency analysis, are included in Figure 8.

None of the Republican River projects have full longitudinal toe protection. The fully functional project (RR2) has some limited toe protection on the downstream end of the project. The success of Project RR2 is not an indicator of the merits of toe protection due to the projects atypical design, described above. Conversely both non-fully functioning projects (RR1 and RR3) lack both keys behind weirs and toe protection. As the failure mode for RR1 and RR3 is flanking, the lack of keys and toe protection seems to be the likely reason for their failure. The difference in level of success between the similar designs of RR1 and RR3 indicate that additional factors such as bank material and channel plan-form characteristics play a major role in the success of bank stabilization projects.

No failures were observed at any of the other sites analyzed in this study. 


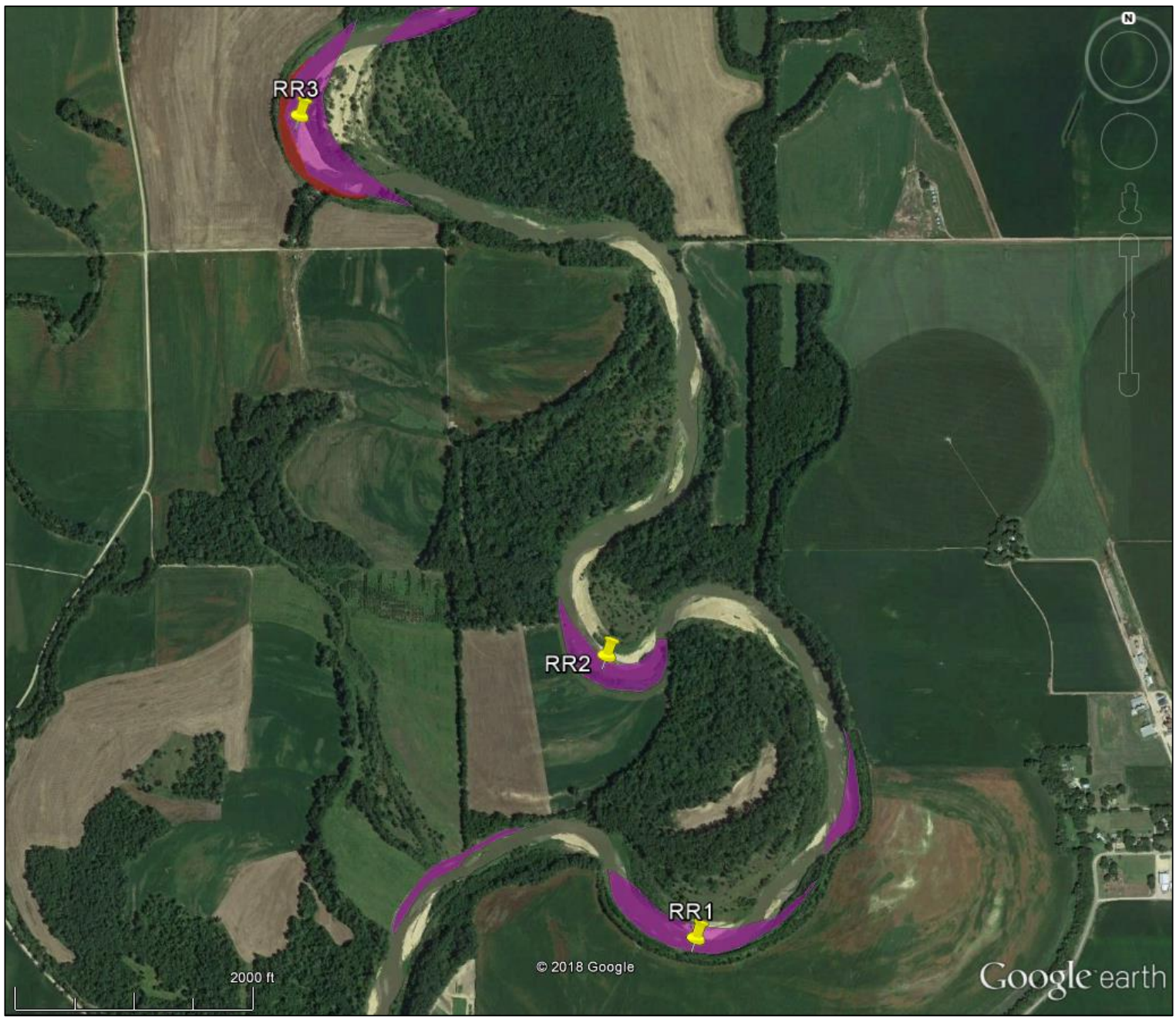

Figure 5. Republican River sites, general location map.
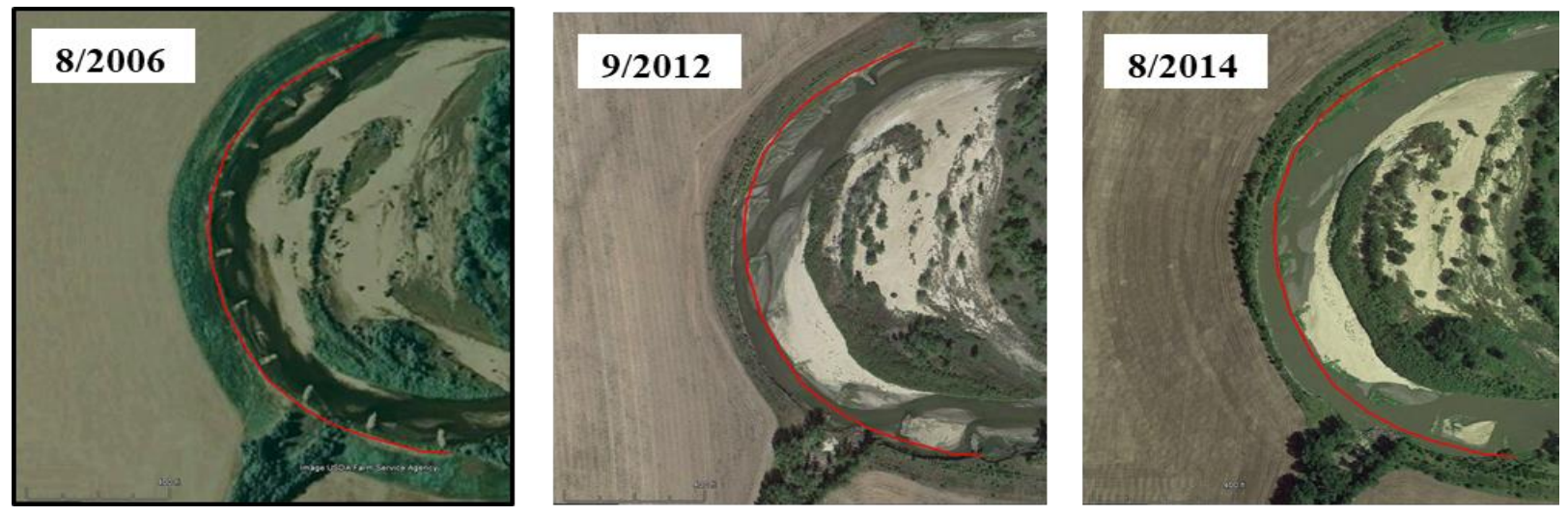

Figure 6. RR3 project site - Post construction (8/2006), After failure (9/2012) and (8/2014). (Red line indicates location of 2006 bank) 
ERDC/TN RSM-20-1

January 2020

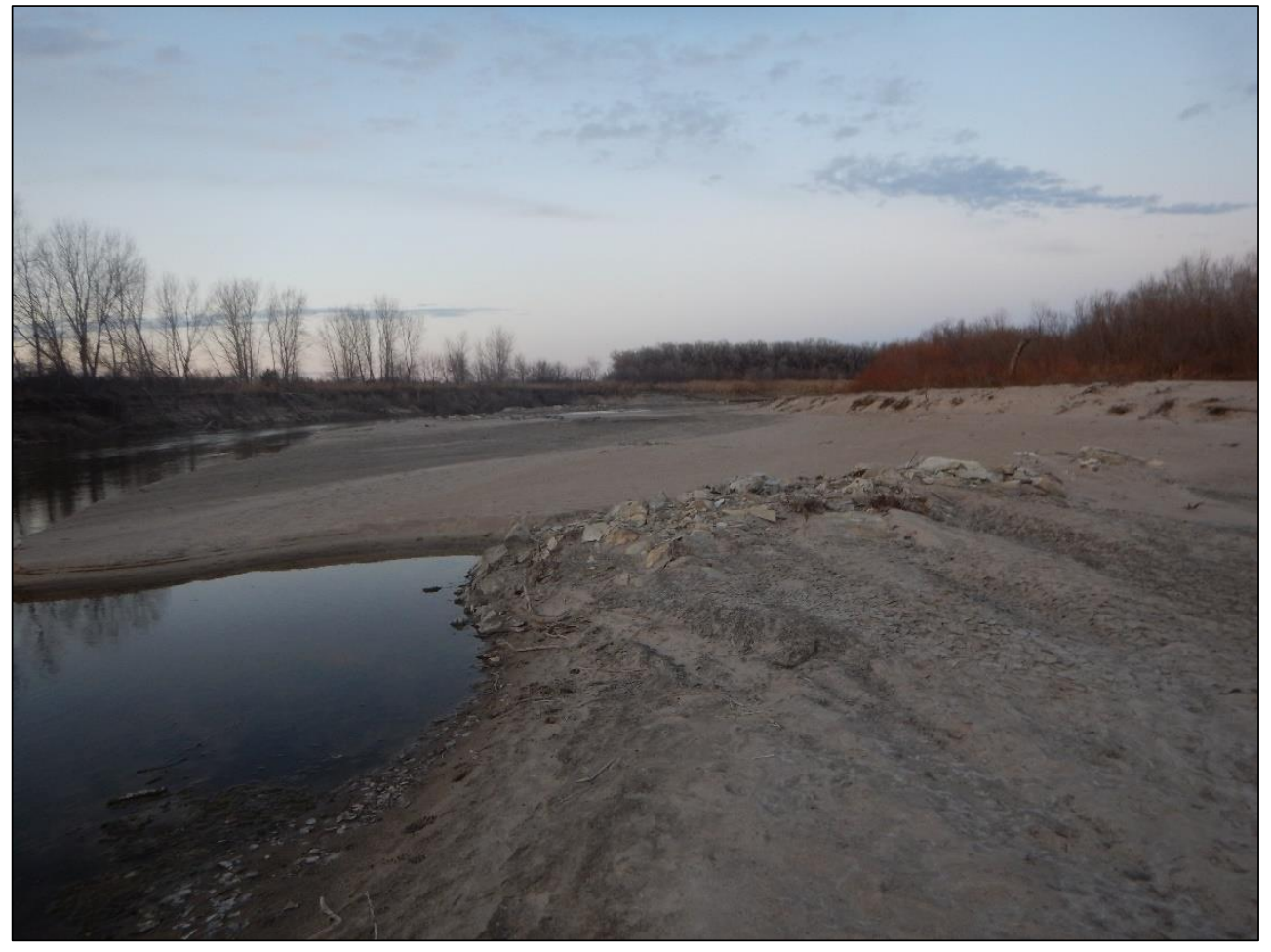

Figure 7. RR1 failure - Flanked structure buried in point bar.

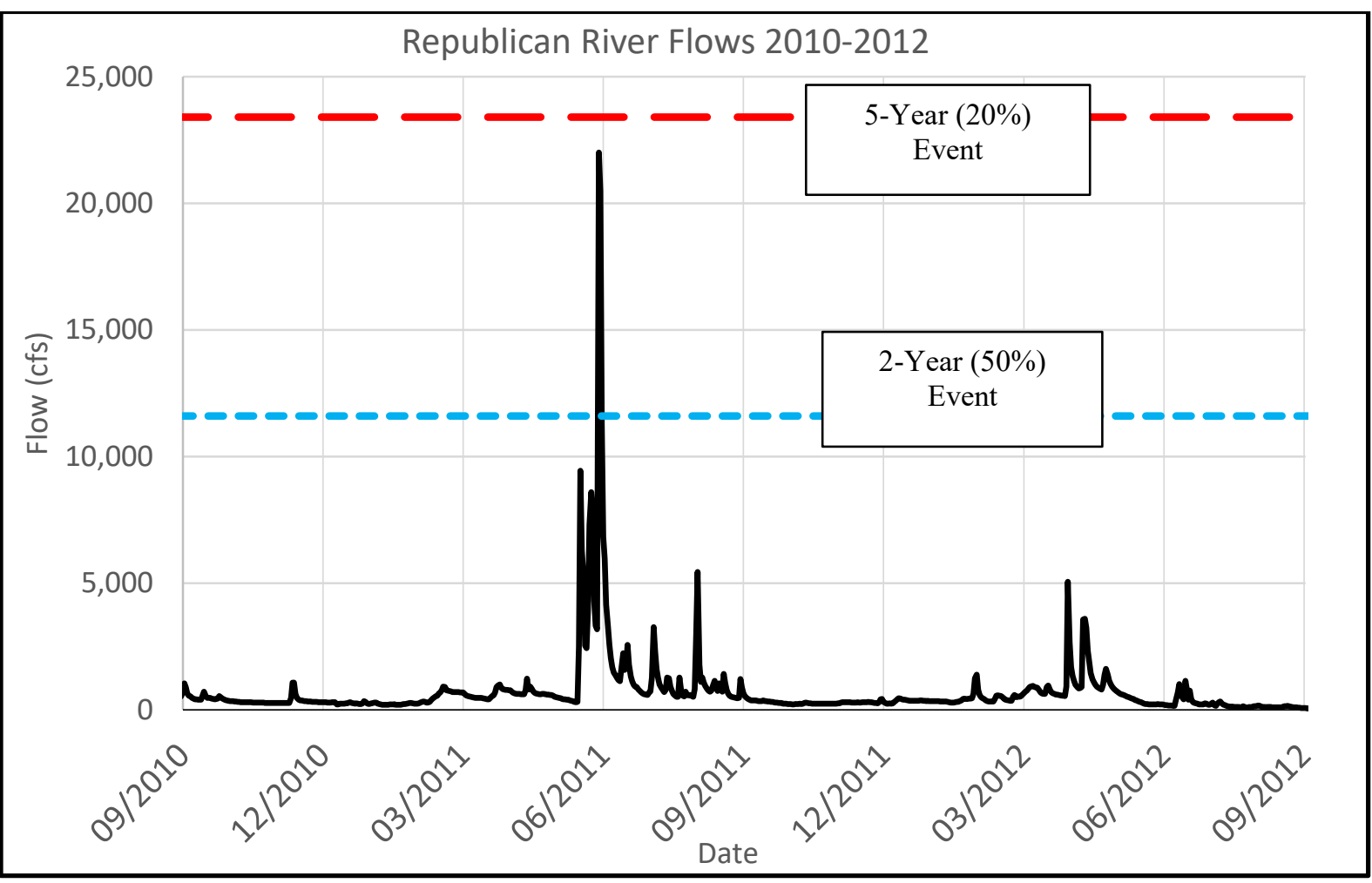

Figure 8. Republican River flows 2010-2012. 
ROCK DEGRADATION: Rock quality degradation was occurring at most sites. This appeared more problematic for bendway weirs because fragmenting rock could be readily washed away from weir tips and crests. These sites were still providing bank stabilization, even though the weirs were sustaining damage. Figure 9 shows rock degradation of bendway weirs observed during field assessments. The rock has fractured, effectively reducing its size and ability to resist erosive forces. Design documentation, including rock size, gradation, and quality is not available for these projects; therefore, the cause of rock degradation is unable to be deduced.
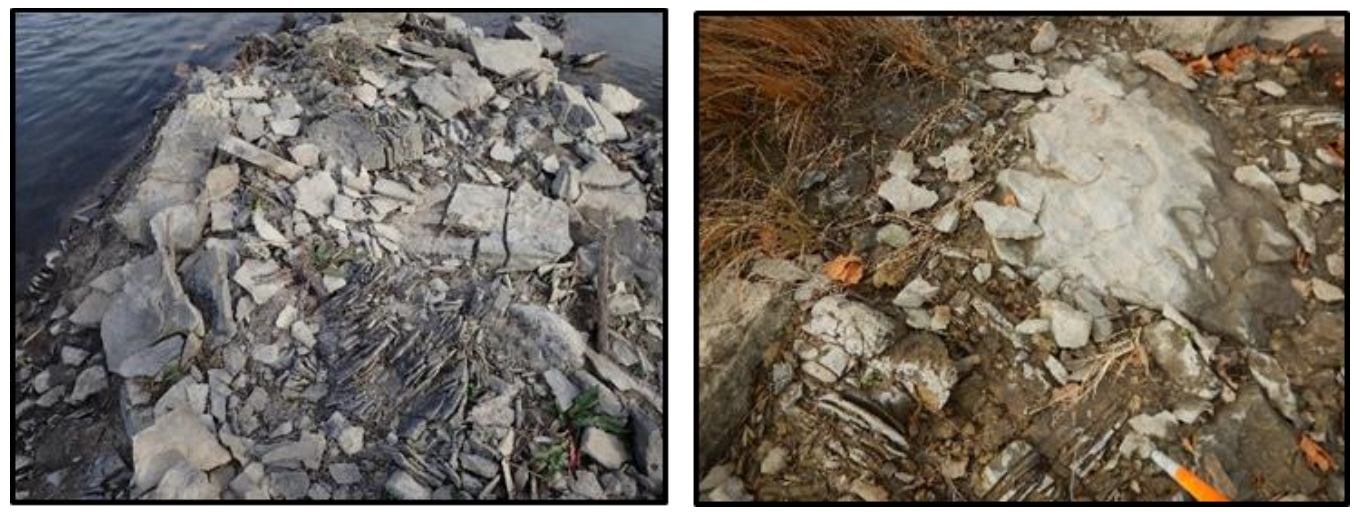

Figure 9. Weathering and degradation of bendway weir rock at RR1.

PROJECT SUCCESS: The projects assessed for this study differed in their design goals and level of robustness. The Section 14 projects are more robust in their design as they, by definition, protect critical public infrastructure. The State of Kansas projects are less robust in their design, and more purposeful in their site selection, as their goal was sediment reduction to downstream reservoirs, and project failure does not result in catastrophic failure of infrastructure. Two major design types were included: (1) baffle dikes with longitudinal toe protection and (2) bendway weirs with or without toe protection.

The projects with baffle dikes and toe protection appeared universally successful at trapping sediment and stabilizing the bank, with vegetation being established within a couple years. Examples showing successful baffle dikes and toe protection are shown in Figure 10.

The projects with bendway weirs were likewise effective if sufficient toe protection or keys were included in the design to prevent flanking. Examples showing successful bendway weirs with toe protection are shown in Figure 11. 
ERDC/TN RSM-20-1

January 2020

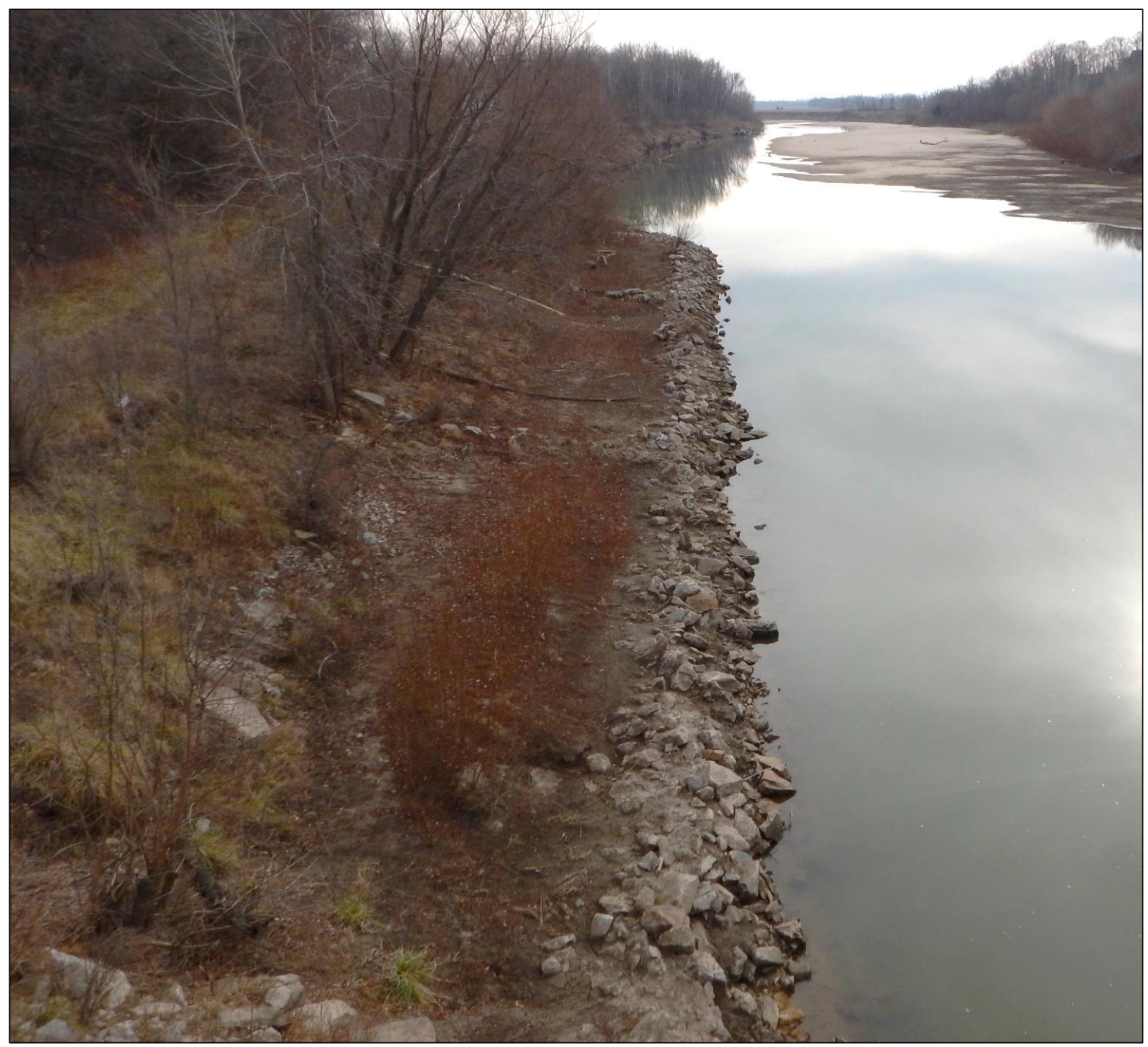

Figure 10. Successful baffle dike with longitudinal peaked stone toe protection and tiebacks at Highway 6 Section 14 project. Note significant sediment deposition between dikes.

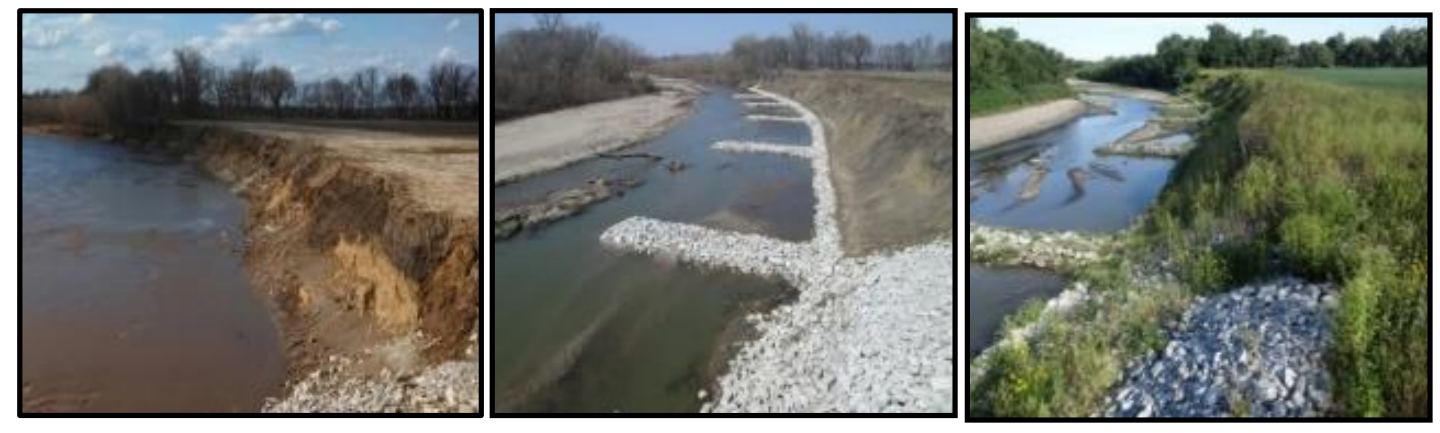

Figure 11. Successful bendway weirs with toe protection - Initial condition (left photo), after construction (middle photo), current condition Highway N (right photo). 
DESIGN SUMMARY: A summary of the key features and success rate of projects assessed for this study and reported in this RSM-TN is included in Table 5.

Table 5. Project features summary table.

\begin{tabular}{|c|c|c|c|c|c|c|c|}
\hline Basin & Site & $\%$ Success & $\begin{array}{c}\text { Toe } \\
\text { Protection }\end{array}$ & $\begin{array}{c}\text { Full } \\
\text { Revetment }\end{array}$ & Keys & Weirs & $\begin{array}{l}\text { Baffle } \\
\text { Dikes }\end{array}$ \\
\hline \multirow{3}{*}{ 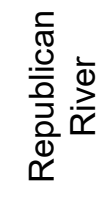 } & RR1 & $10 \%$ & NO & NO & NO & YES & NO \\
\hline & $\mathrm{RR} 2$ & $100 \%$ & YES* & NO & YES & YES & NO \\
\hline & RR3 & $75 \%$ & NO & NO & NO & YES & NO \\
\hline \multirow{4}{*}{ 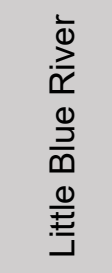 } & LB1 & $100 \%$ & YES & NO & YES & YES & NO \\
\hline & LB2 & $100 \%$ & YES & NO & YES & YES & NO \\
\hline & LB3 & $100 \%$ & YES & NO & YES & YES & NO \\
\hline & LB4 & $100 \%$ & YES & NO & YES & YES & NO \\
\hline \multirow{3}{*}{ 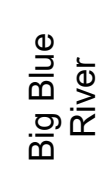 } & BB1 & $100 \%$ & NO & NO & YES & YES & NO \\
\hline & BB2 & $100 \%$ & YES & NO & YES & YES & NO \\
\hline & BB3 & $100 \%$ & YES & NO & YES & YES & NO \\
\hline \multirow{8}{*}{ 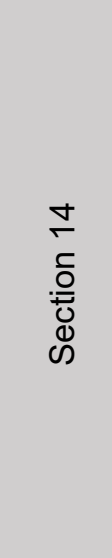 } & US 169 & $100 \%$ & YES & NO & YES & NO & YES \\
\hline & Route B & $100 \%$ & YES & YES & YES & YES & YES \\
\hline & Route EE & $100 \%$ & YES & NO & YES & NO & YES \\
\hline & Route H & $100 \%$ & YES & NO & YES & NO & YES \\
\hline & $\begin{array}{l}\text { Muddy } \\
\text { Creek }\end{array}$ & $100 \%$ & YES & YES & YES & NO & YES \\
\hline & Route N & $100 \%$ ** & YES & YES & YES & YES & NO \\
\hline & Route W & $100 \%$ & YES & YES & YES & NO & YES \\
\hline & Highway 6 & $100 \%$ & YES & NO & YES & NO & YES \\
\hline
\end{tabular}

* Atypical toe protection downstream of lowest weir

**Success assessed after the weirs were repaired

LESSONS LEARNED: Field assessments allowed USACE personnel to evaluate how previously constructed bank stabilization projects are functioning. Project failures, such as project RR3 on the Republican River, illustrate potential shortcomings in project designs. Conversely, the success of projects with varying degrees of robustness can help engineers avoid overdesigning future projects. The field assessments performed for this study shed light on potential pitfalls and limitations in implementing project designs in the field. Finally, projects should be monitored to ensure the failure of a single project feature does not lead to failure of the entire project.

CONCLUSION: This study included analysis of bank stabilization as a means of regional sediment management using assessments of 18 projects within the Kansas River and Grand River Basins. This study also distilled lessons learned from project successes and failures. Based on this analysis, the 
cost of constructing bank stabilization projects similar in design to the State of Kansas projects will offset the cost of dredging an equivalent volume of material within 1-2 years, with most projects functioning for decades. Of the State of Kansas projects analyzed in this study, stabilization of erosion hot spots is, on average, 14 times more cost effective than traditional dredging over a 20year assumed life. For the Section 14 projects, the dredging cost approximately equals the project cost; however, these projects will likely last beyond the assumed 20-year life. The Section 14 projects were economically justified based on benefits to critical infrastructure alone.

Many factors determine the success or failure of bank stabilization projects; however, based on the projects analyzed in this study the following factors appear to impact the success of the projects:

- Toe protection and keying project features into the banks are vital to project success. Bendway weirs on their own seldom provide whole bank protection.

- Toe protection with baffle dikes appeared to induce larger quantities of sediment deposition and vegetation establishment that could lead to more self-sustaining and longer-term bank stabilization.

- Projects should be monitored and adaptively managed to ensure failure of a single project feature does not result in failure of the entire project.

ADDITIONAL INFORMATION: This RSM-TN was prepared by Aaron Williams, P.E., and John Shelley, Ph.D., P.E., hydraulic engineers with the USACE NWK. This study was conducted as an activity of the USACE National RSM Program, a Navigation Research, Development, and Technology portfolio program administered by Headquarters, USACE. For information regarding the National RSM Program, please consult http://rsm.usace.army.mil or contact the National RSM Program Manager, Dr. Katherine Brutsché (Katherine.E.Brutsche@usace.army.mil). For information regarding this RSM-TN, please contact Aaron Williams (aaron.r.williams@usace.army.mil) or John Shelleyjohn.shelley@usace.army.mil.

This RSM-TN should be cited as follows:

Williams, A., and J. Shelley. 2020. Effects of Bank Stabilization on Regional Sediment Management: Lessons Learned from the Kansas River and Grand River Basins. ERDC/TN RSM-20-1. Vicksburg, MS: US Army Engineer Research and Development Center. http://dx.doi.org/10.21079/11681/35313

\section{REFERENCES}

Biedenharn, S., C. Thorne, and C. Watson. 2006. "Wash Load/Bed Material Load Concept in Regional Sediment Management." Proceedings of the Eighth Federal Interagency Sedimentation Conference (8thFISC). Reno, NV. https://pubs.usgs.gov/misc/FISC_1947-2006/pdf/1st-7thFISCs-CD/

Einstein, H. A. 1950. The Bed-Load Function for Sediment Transportation in Open-Channel Flows. Washington, DC: US Department of Agriculture, Soil Conservation Service.

Gnau, C. 2013. Streambank Stabilization Effectiveness on Little and Big Blue Rivers. Presentation at the Governor's Conference on the Future of Water in Kansas. October 25, 2013.

Juracek, K. E., and A. C. Ziegler. 2009. "Estimation of Sediment Sources Using Selected Chemical Tracers in the Perry Lake Basin, Kansas, USA.” International Journal of Sediment Research 24: 108-125. https://doi.org/10.1016/S1001-6279(09)60020-2 
KWO (Kansas Water Office). 2016. John Redmond Reservoir Dredging Project-Phase I Complete. Topeka, KS: Kansas Water Office. https://kwo.ks.gov/admin-pages/news-content/2017/06/09/john-redmond-reservoirdredging-project--phase-i-complete-october-2016

Shelley, J., M. Boyer, J. Granet, and A. Williams. 2016. Environmental Benefits of Restoring Sediment Continuity to the Kansas River. ERDC/CHL CHETN-XIV-50. Vicksburg, MS: US Army Engineer Research and Development Center. http://hdl.handle.net/11681/20279

Shelley, J. E. 2019. Analysis for a Hydrosuction Sediment Removal System at Tuttle Creek Lake, KS. ERDC/TN RSM19-5. Vicksburg, MS: US Army Engineer Research and Development Center.

USACE (US Army Corps of Engineers). 2011. Kansas River Basin Regional Sediment Management Section 204 Stream and River Channel Assessment. Prepared by Gulf South Research Corporation and The Watershed Institute for the US Army Corps of Engineers, Kansas City District. http://cdm16884.contentdm.oclc.org/cdm/ref/collection/p16884coll78/id/144

US Department of Agriculture, Soil Conservation Service. Technical Bulletin No. 1026. Washington, DC. https://naldc.nal.usda.gov/download/CAT86201017/PDF

NOTE: The contents of this technical note are not to be used for advertising, publication, or promotional purposes. Citation of trade names does not constitute an official endorsement or approval of the use of such products. 